\title{
Induction of CNS a-synuclein pathology by fibrillar and non-amyloidogenic recombinant a-synuclein
}

\author{
Amanda N Sacino, Mieu Brooks, Nicholas H McGarvey, Alex B McKinney, Michael A Thomas, Yona Levites, \\ Yong Ran, Todd E Golde* and Benoit I Giasson*
}

\begin{abstract}
Background: a-Synuclein (aS) is the major component of several types of brain inclusions including Lewy bodies, a hallmark of Parkinson's disease. Aberrant aggregation of aS also is associated with cellular demise in multiple neurologic disorders collectively referred to as synucleinopathies. Recent studies demonstrate the induction of as pathology by a single intracerebral injection of exogenous amyloidogenic as in adult non-transgenic and transgenic mice expressing human aS. To further investigate the mechanism of pathology induction and evaluate an experimental paradigm with potential for higher throughput, we performed similar studies in neonatal mice injected with aS.
\end{abstract}

Results: In non-transgenic mice, we observed limited induction of neuronal aS inclusions predominantly 8 months after brain injection of aggregated, amyloidogenic human aS. More robust inclusion pathology was induced in transgenic mice expressing wild-type human aS (line M20), and inclusion pathology was observed at earlier time points. Injection of a non-amyloidogenic ( $\Delta 71-82)$ deletion protein of aS was also able to induce similar pathology in a subset of M20 transgenic mice. M20 transgenic mice injected with amyloidogenic or non-amyloidogenic aS demonstrated a delayed and robust induction of brain neuroinflammation that occurs in mice with or without aS pathological inclusions implicating this mechanism in aggregate formation.

Conclusions: The finding that a non-amyloidogenic $\Delta 71-82$ aS can induce pathology calls into question the simple interpretation that exogenous aS catalyzes aggregation and spread of intracellular as pathology solely through a nucleation dependent conformational templating mechanism. These results indicate that several mechanisms may act synergistically or independently to promote the spread of as pathology.

Keywords: Amyloid, Neonatal, Parkinson's disease, Pathology, a-Synuclein, Transgenic mice

\section{Background}

A characteristic of Parkinson's disease, the most common neurodegenerative movement disorder, is the presence of intraneuronal Lewy bodies (LBs) in neurons. These inclusions are formed from the amyloidogenic aggregation of the normally soluble presynaptic protein $\alpha$-synuclein $(\alpha S)$. $\alpha \mathrm{S}$ brain inclusions also are present in a spectrum of neurodegenerative disorders known as $\alpha$-synucleinopathies [1-3]. A direct causal role for $\alpha \mathrm{S}$ in neurodegeneration is

\footnotetext{
*Correspondence: tgolde@ufl.edu; bgiasson@ufl.edu

Center for Translational Research in Neurodegenerative Disease, Department of Neuroscience, BMS Building J-483, University of Florida College of Medicine, 1275 Center Drive, PO Box 100159, Gainesville, FL 32610, USA
}

supported by missense mutations or increased copy number of the $\alpha \mathrm{S}$ gene $(S N C A)$ in some patients with Parkinson's disease and the related disorder dementia with Lewy bodies [4-11]. Despite a large number of experimental studies, the precise mechanism(s) of $\alpha \mathrm{S}$ toxicity is still not resolved, although multiple lines of evidence support the hypothesis that $\alpha \mathrm{S}$ aggregation is linked to cellular demise $[1,12]$.

$\alpha$-Synucleinopathies are progressive diseases and in recent years there have been increasing efforts to identify the mechanisms involved in intracerebral spread of pathology, as it is reasoned that therapies that could slow or halt pathology spread would likely be disease modifying. Recently, 
several experimental and pathological studies have suggested that spreading of $\alpha \mathrm{S}$ pathology might occur via a seeded conformational-templating protein aggregation mechanism. For example, LB formation was observed in fetal dopaminergic neurons of a subset of PD patients that received striatal transplants as an attempted therapeutic intervention [13-15]. A seeding mechanism would also generally be consistent with the proposed Braak staging of disease that appears to follow neuroanatomical pathways [16]. Experimentally it was reported that the intracerebral injection of extracts from moribund A53T human $\alpha \mathrm{S}$ transgenic ( $\mathrm{Tg}$ ) mice (line M83) that develop a late onset severe motor phenotype associated with widespread formation of neuronal $\alpha \mathrm{S}$ inclusions into younger healthy M83 Tg mice could induce these cellular and phenotypic pathologies [17-19]. Furthermore, brain injection of pre-formed recombinant $\alpha \mathrm{S}$ fibrils into M83 Tg mice can also induce $\alpha \mathrm{S}$ pathology within brain regions that are distant from the injection site [18], suggesting that these $\alpha \mathrm{S}$ species can initiate and perhaps lead to transmission of $\alpha \mathrm{S}$ pathology. Induction of brain $\alpha \mathrm{S}$ pathology was also reported in non-Tg (nTg) mice following intrastriatal injection of murine fibrillar $\alpha S$ [20]. More recently it was reported that the injection of either preformed human or mouse $\alpha \mathrm{S}$ fibrils in the substantia nigra of nTg mice could also induce neuronal $\alpha \mathrm{S}$ pathology, but this pathology could only be observed 3 months or more after exposure [21]. Collectively these studies along with numerous in vitro and culture studies support the concept of $\alpha \mathrm{S}$ pathology spread within the brain via a conformational templating mechanism. However, this mechanism of pathology induction remains to be formally proven in vivo, as other possible mechanisms could contribute to $\alpha \mathrm{S}$ inclusion pathology induction including disruption of proteostasis and innate immune activation [22-25].

To further elucidate the mechanisms associated with the induction of intraneuronal $\alpha \mathrm{S}$ inclusion pathology resulting from exogenous $\alpha \mathrm{S}$ challenge and to evaluate a potentially higher throughput experimental paradigm, we injected amyloidogenic and non-amyloidogenic forms of $\alpha S$ into the brain of neonatal nTg and M20 Tg mice expressing wild-type human $\alpha \mathrm{S}$. Neonatal injection is a significantly easier and faster surgical procedure than stereotactic injection in the adult brain, mainly because cryo-anesthesia can be utilized and the skull is still soft and flexible. These studies reveal that neonatal cerebral injection of amyloidogenic $\alpha \mathrm{S}$ results in limited neuronal $\alpha \mathrm{S}$ inclusions in $\mathrm{nTg}$ mice that are observed predominantly 8 months after injection. Similar studies in M20 Tg mice also revealed a lag time in the formation of detectable $\alpha \mathrm{S}$ pathology, but pathology was more widespread throughout the neuroaxis and was induced by the injection of both amyloidogenic and nonamyloidogenic forms of $\alpha S$.

\section{Material and methods Antibodies}

pSer129 is a mouse monoclonal antibody specific to $\alpha \mathrm{S}$ phosphorylated at Ser129 [26]. Syn211 and LB509 are mouse monoclonal antibodies specific for human $\alpha \mathrm{S}$ $[27,28]$. SNL-1 is a rabbit polyclonal antibody raised against a synthetic peptide corresponding to amino acids 104-119 of $\alpha \mathrm{S}$ and specifically reacts with both murine and human $\alpha \mathrm{S}$ [27]. SNL-4 is a rabbit polyclonal antibody raised against a synthetic peptide corresponding to amino acids $2-12$ of $\alpha S$ [27]. Syn506 is a conformational anti- $\alpha S$ mouse monoclonal antibody that preferentially detects $\alpha S$ in pathological inclusions [29,30]. Anti-p62 (SQSTM1; Proteintech; Chicago, IL), anti-glial fibrillary acidic protein (GFAP; Promega; Madison, WI), and anti-ionized calcium-binding adaptor molecule 1 (IBA-1; DAKO; Glostrio, Denmark) are rabbit polyclonal antibodies. An anti-glyceraldehyde-3-phosphate dehydrogenase (GAPDH) mouse monoclonal antibody was obtained from Biodesign (Memphis, TN).

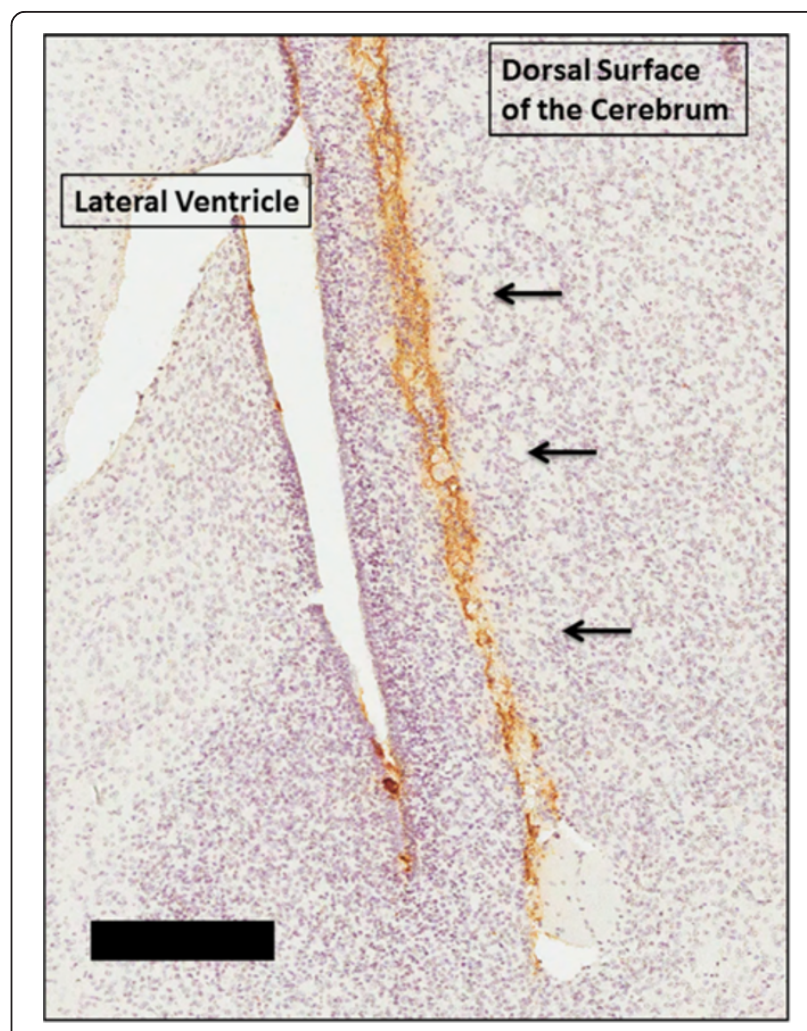

Figure 1 Detection of injected human aS in the needle track 2 days post neonatal injection. $\mathrm{IHC}$ staining with human aS specific antibody LB509 2 days after neonatal injection of 25 mg 21-140 human aS fibrils in nTg mice. Staining shows the presence of human aS in the brain injection tract adjacent to the lateral ventricle in the cerebrum (black arrows). The tissue section was counterstained with hematoxylin. Scale bar $=250 \mu \mathrm{m}$. 


\section{nTg mice and M20 aS Tg mice}

All procedures were performed according to the NIH Guide for the Care and Use of Experimental Animals and were approved by the University of Florida Institutional Animal Care and Use Committee. BL6C3HF1 mice (Charles River Laboratories International Inc, Wilmington, $\mathrm{MA}$ ) have the same strain background as $\alpha \mathrm{S}$ Tg mice (line M20) and were used as nTg mice. The M20 Tg mice express human wild-type $\alpha \mathrm{S}$ under the control of the mouse PrP promoter and these mice do not develop any intrinsic phenotype or $\alpha \mathrm{S}$ pathology [31,32]. Hemizygous M20 Tg male mice were mated with female BL6C3HF1 mice and genotyped by PCR, but also confirmed by immunohistochemical (IHC) staining of mouse brain section with antihuman $\alpha$ S antibody Syn211. All animals were housed 3 to 5 to a cage and maintained on ad libitum food and water with a $12 \mathrm{~h}$ light/dark cycle.

\section{Brain aS injection into neonatal mice}

Bilateral neonatal (P0) injections of $\alpha \mathrm{S}$ proteins were performed by inserting the needle about $0.5 \mathrm{~cm}$ deep into the brain just lateral to the lateral ventricles in the cerebrum (see Figure 1) using cryo-anesthesia as described previously [33]. In brief, P0 pups were cryo-anesthetized on ice for up to 5 minutes. Each pup received bilateral injections of $\alpha \mathrm{S}$ proteins. Injections were made using a $10 \mu \mathrm{L}$ Hamilton syringe with a 30-gauge needle. Different syringes were used for each type of protein to prevent any contamination. Post-injection, the pups were placed on a heating pad for recovery before being returned to their home cage.

\section{Expression and purification of recombinant aS proteins} The pRK172 cDNA constructions expressing full-length human $\alpha \mathrm{S}$, human $\alpha \mathrm{S}$ with amino acid 71-82 deletion ( $\Delta 71-82$ ), and $\mathrm{N}$-terminal truncated $21-140 \alpha \mathrm{S}$ (with a Met codon added before amino acid 21) were previously described [34,35]. $\alpha \mathrm{S}$ proteins were expressed in E. coli BL21 (DE3) and purified to homogeneity by size exclusion (Superdex 200 gel filtration) and ion exchanged (Mono Q) chromatographies as previously described [34,36].

\section{Fibril preparation of recombinant aS for mouse brain injection}

21-140 $\alpha$ S protein was assembled into filaments by incubation at $37^{\circ} \mathrm{C}$ at $5 \mathrm{mg} / \mathrm{ml}$ in sterile phosphate buffered saline (PBS, Invitrogen) with continuous shaking at $1050 \mathrm{rpm}$ (Thermomixer R, Eppendorf, Westbury, NY). $\alpha \mathrm{S}$ amyloid fibril assembly was monitored as previously described with K114 fluorometry [35,37]. $\alpha$ S fibrils were diluted in sterile PBS and treated by water bath sonication for 2 hours. These fibrils were tested for induction of intracellular amyloid inclusion formation as previously described [38,39].

\section{Immunohistochemical analysis}

Mice were sacrificed with $\mathrm{CO}_{2}$ euthanization and perfused with PBS/heparin, followed by perfusion with either $70 \%$

Table 1 Summary of neonatal $n T g$ mice injected with aS proteins ${ }^{a}$

\begin{tabular}{|c|c|c|c|c|}
\hline Mouse strain & Inoculum & Age at harvest & Number of mice & Pathological findings \\
\hline C57BL6/C3H & fib aS $(2 \mu \mathrm{l}$ of $1 \mathrm{mg} / \mathrm{ml})$ & 1 month & 9 & No inclusions \\
\hline C57BL6/C3H & fib as (2 $\mu \mathrm{l}$ of $1 \mathrm{mg} / \mathrm{ml})$ & 2 months & 3 & No inclusions \\
\hline C57BL6/C3H & fib as $(2 \mu \mathrm{l}$ of $1 \mathrm{mg} / \mathrm{ml})$ & 4 months & 6 & No inclusions \\
\hline C57BL6/C3H & fib as $(2 \mu \mathrm{l}$ of $1 \mathrm{mg} / \mathrm{ml})$ & 8 months & 4 & No inclusions \\
\hline C57BL6/C3H & fib as $(5 \mu \mathrm{l}$ of $5 \mathrm{mg} / \mathrm{ml})$ & 1 month & 9 & No inclusions \\
\hline C57BL6/C3H & fib as $(5 \mu \mathrm{l}$ of $5 \mathrm{mg} / \mathrm{ml})$ & 2 months & 7 & 1 of 7 mice show rare inclusions ${ }^{b}$ \\
\hline C57BL6/C3H & fib as $(5 \mu \mathrm{l}$ of $5 \mathrm{mg} / \mathrm{ml})$ & 4 months & 3 & No inclusions \\
\hline C57BL6/C3H & fib aS $(5 \mu \mathrm{l}$ of $5 \mathrm{mg} / \mathrm{ml})$ & 8 months & 13 & 4 of 13 mice show rare cortical inclusions \\
\hline C57BL6/C3H & $\Delta 71-82$ as $(2 \mu \mathrm{l}$ of $1 \mathrm{mg} / \mathrm{ml})$ & 1 month & 4 & No inclusions \\
\hline C57BL6/C3H & $\Delta 71-82$ as $(2 \mu \mathrm{l}$ of $1 \mathrm{mg} / \mathrm{ml})$ & 2 months & 3 & No inclusions \\
\hline C57BL6/C3H & $\Delta 71-82$ as $(2 \mu \mathrm{l}$ of $1 \mathrm{mg} / \mathrm{ml})$ & 4 months & 2 & No inclusions \\
\hline C57BL6/C3H & $\Delta 71-82$ as $(5 \mu \mathrm{l}$ of $5 \mathrm{mg} / \mathrm{ml})$ & 1 month & 9 & No inclusions \\
\hline C57BL6/C3H & $\Delta 71-82$ as $(5 \mu \mathrm{l}$ of $5 \mathrm{mg} / \mathrm{ml})$ & 2 months & 8 & No inclusions \\
\hline C57BL6/C3H & $\Delta 71-82$ as $(5 \mu \mathrm{l}$ of $5 \mathrm{mg} / \mathrm{ml})$ & 8 months & 6 & No inclusions \\
\hline
\end{tabular}

${ }^{a}$ Tg mice were injected with 21-140 human aS fibrils (fib) or $\Delta 71-82$ human aS at the different dosages indicated and analyzed for aS pathology at 1-8 months post-injection using pSer129 and Syn506 antibodies.

${ }^{\mathrm{b}}$ Sparse inclusions were observed in the midbrain area of 1 mouse.

' See Figure 2 for a schematic neuroanatomical map showing the distribution of aS pathology. 


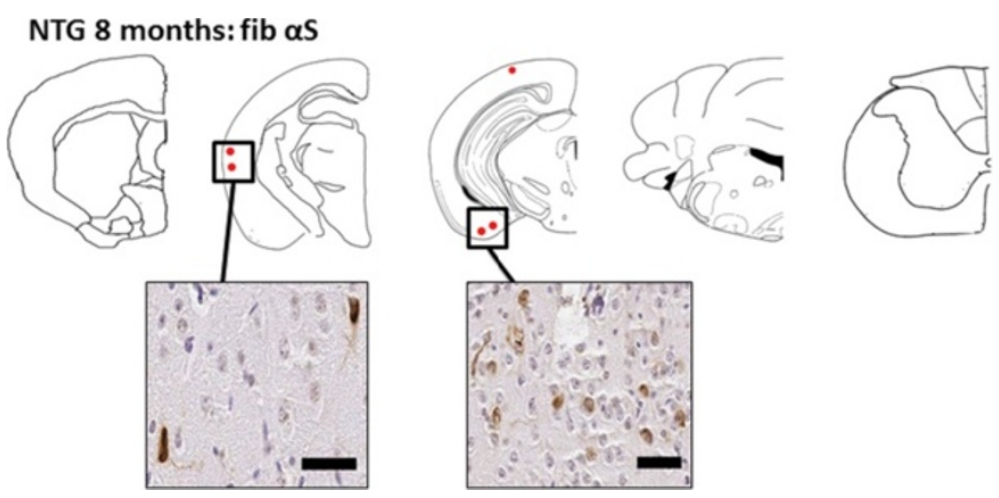

Figure 2 Schematic summary showing predominant cortical distribution of aS pathology in $\mathrm{nTg}$ mice 8 months after brain neonatal injection of fibrillar 21-140 aS. nTg mice injected with $25 \mu \mathrm{g}$ 21-140 fibrillar (fib) aS. Map shows rostral-caudal distribution of aS inclusions via coronal sections. Equivalent density and distribution of aS pathology was seen bilaterally. Pathology was detected with antibodies pSer129 and Syn506. As shown in representative images, small, rounded perinuclear aS inclusion and neuritic profiles were found sparsely distributed in the cortex. The distribution of inclusions was very similar in all mice with pathology. Scale bar $=50 \mu \mathrm{m}$.

ethanol/150 $\mathrm{mM} \mathrm{NaCl}$ or PBS buffered formalin. The brain and spinal cord were then removed and fixed for at least 24 hours in the respective fixatives used for perfusion. As previously described, tissues were dehydrated at room temperature through a series of ethanol solutions, followed by xylene and then were infiltrated with paraffin at $60^{\circ} \mathrm{C}$ [40]. The tissues were then embedded into paraffin blocks, which were cut into $7 \mu \mathrm{m}$ sections. Immunostaining of the sections was performed using previously described methods [40] with the avidin-biotin complex (ABC) system (Vectastain ABC Elite Kit, Vector Laboratories, Burlingame, $\mathrm{CA}$ ), and with immunocomplex visualization via chromogen 3, 3'-diaminobenzidine. Sections were counterstained with hematoxylin. All slides were scanned using an Aperio ScanScope CS (40× magnification; Aperio Technologies Inc., Vista, CA), and images of representative areas of $\alpha \mathrm{S}$ pathology were taken using the ImageScopeTM software (40× magnification; Aperio Technologies Inc.).

\section{Double-labeling immunofluorescence analysis of mouse brain tissue}

Paraffin-embedded tissue sections were deparaffinized and hydrated through a series of graded ethanol solutions followed by $0.1 \mathrm{M}$ Tris, $\mathrm{pH}$ 7.6. The sections were blocked with $5 \%$ dry milk/0.1 M Tris, $\mathrm{pH} 7.6$, and were incubated simultaneously with combinations of primary antibodies diluted in 5\% dry milk/0.1 M Tris, $\mathrm{pH}$ 7.6. After extensive washing, sections were incubated with secondary antibodies conjugated to Alexa 594 or Alexa 488 (Invitrogen; Eugene, OR). Sections were post-fixed with formalin, incubated with Sudan Black, and stained with $5 \mu \mathrm{g} / \mathrm{ml} \mathrm{4,} 6$ diamindino-2-phenylindole (DAPI). The sections were coverslipped with Fluoromount-G (SouthernBiotech, Birmingham, AL) and visualized using an Olympus BX51 microscope mounted with a DP71 Olympus digital camera to capture images.

\section{Immunoblotting analysis}

Mouse brains were lysed in 2\% SDS/50 mM Tris pH 7.5 by sonication and heated to $100^{\circ} \mathrm{C}$ for 10 minutes. Protein concentration was quantified using the bicinchoninic acid (BCA) assay and bovine serum albumin as a standard (Pierce Biotechnology; Rockford, IL). $15 \mu \mathrm{g}$ of total protein

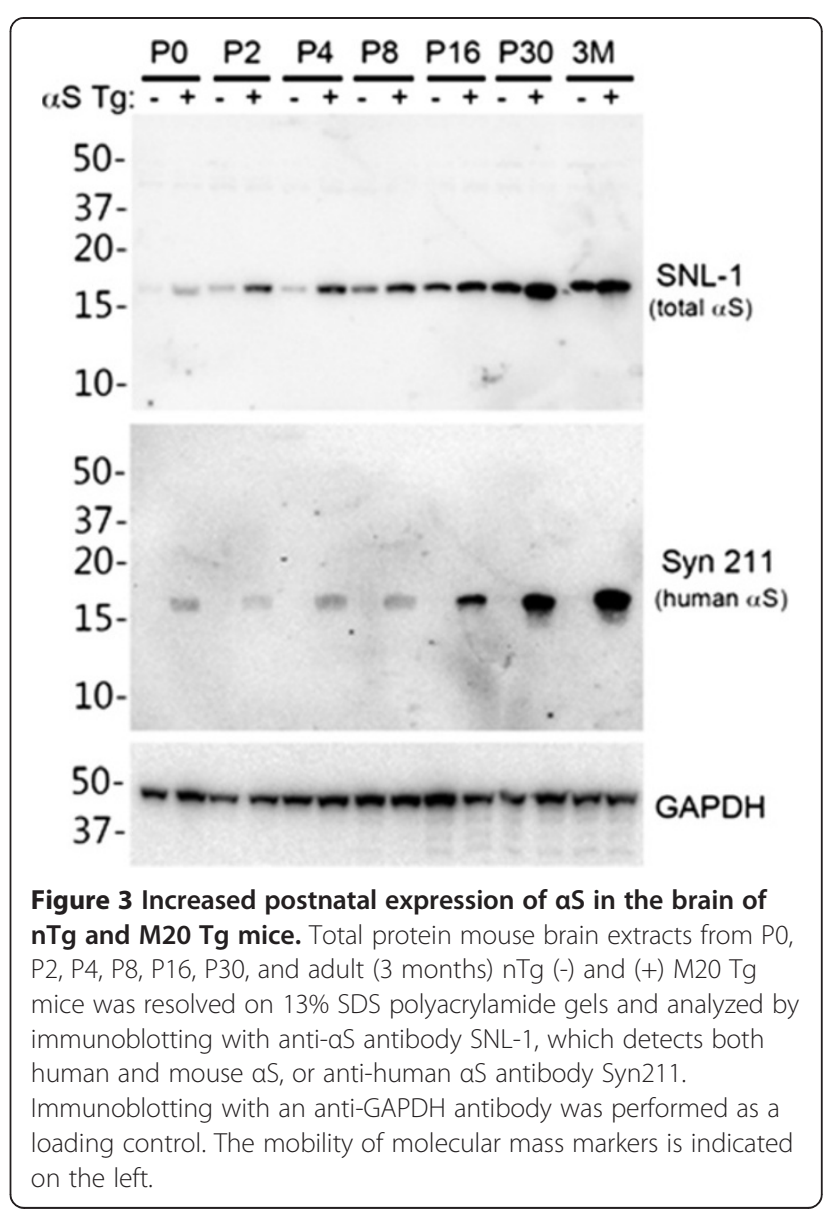


Table 2 Summary of neonatal M20 Tg mice injected with aS proteins ${ }^{\mathrm{a}}$

\begin{tabular}{|c|c|c|c|c|}
\hline Mouse strain & Inoculums & Age at harvest & Number of mice & Pathological findings \\
\hline M20 (WT aS) & fib aS $(2 \mu \mathrm{l}$ of $1 \mathrm{mg} / \mathrm{ml})$ & 1 month & 7 & No inclusions \\
\hline M20 (WT aS) & fib as $(2 \mu \mathrm{l}$ of $1 \mathrm{mg} / \mathrm{ml})$ & 2 months & 5 & No inclusions \\
\hline M20 (WT aS) & fib as $(2 \mu \mathrm{l}$ of $1 \mathrm{mg} / \mathrm{ml})$ & 4 months & 3 & No inclusions \\
\hline M20 (WT aS) & fib as (2 $\mu \mathrm{l}$ of $1 \mathrm{mg} / \mathrm{ml})$ & 8 months & 4 & 4 of 4 mice show sparse cortical pathology \\
\hline M20 (WT aS) & fib as $(5 \mu \mathrm{l}$ of $5 \mathrm{mg} / \mathrm{ml})$ & 1 month & 4 & 3 of 4 mice show sparse cortical pathology \\
\hline M20 (WT aS) & fib as $(5 \mu \mathrm{l}$ of $5 \mathrm{mg} / \mathrm{ml})$ & 2 months & 5 & 4 of 5 mice show sparse cortical pathology \\
\hline M20 (WT aS) & fib as $(5 \mu \mathrm{l}$ of $5 \mathrm{mg} / \mathrm{ml})$ & 4 months & 3 & 2 of 3 mice show sparse cortical pathology \\
\hline M20 (WT aS) & fib as $(5 \mu \mathrm{l}$ of $5 \mathrm{mg} / \mathrm{ml})$ & 8 months & 12 & 12 of 12 mice show abundant pathology ${ }^{\mathrm{b}}$ \\
\hline M20 (WT aS) & $\Delta 71-82$ aS $(2 \mu \mathrm{l}$ of $1 \mathrm{mg} / \mathrm{ml})$ & 1 month & 5 & No inclusions \\
\hline M20 (WT aS) & $\Delta 71-82$ as $(2 \mu \mathrm{l}$ of $1 \mathrm{mg} / \mathrm{ml})$ & 2 months & 5 & No inclusions \\
\hline M20 (WT aS) & $\Delta 71-82$ aS $(2 \mu \mathrm{l}$ of $1 \mathrm{mg} / \mathrm{ml})$ & 4 months & 3 & No inclusions \\
\hline M20 (WT aS) & $\Delta 71-82$ aS $(2 \mu \mathrm{l}$ of $1 \mathrm{mg} / \mathrm{ml})$ & 8 months & 3 & No inclusions \\
\hline M20 (WT aS) & $\Delta 71-82$ aS $(5 \mu \mathrm{l}$ of $5 \mathrm{mg} / \mathrm{ml})$ & 1 month & 7 & No inclusions \\
\hline M20 (WT aS) & $\Delta 71-82$ aS $(5 \mu \mathrm{l}$ of $5 \mathrm{mg} / \mathrm{ml})$ & 2 months & 7 & No inclusions \\
\hline M20 (WT aS) & $\Delta 71-82$ as $(5 \mu \mathrm{l}$ of $5 \mathrm{mg} / \mathrm{ml})$ & 8 months & 6 & 2 out of 6 mice show abundant pathology ${ }^{b}$ \\
\hline
\end{tabular}

${ }^{\mathrm{a}}$ M20 Tg mice were injected with 21-140 human aS fibrils (fib) or $\Delta 71-82$ human aS at the different dosages indicated and analyzed for aS pathology at 1-8 months post-injection using pSer129 and Syn506 antibodies.

${ }^{b}$ See Figure 4 for a schematic neuroanatomical map showing the distribution of as pathology.

was resolved by SDS-PAGE on 13\% polyacrylamide gels, followed by electrophoretic transfer onto nitrocellulose membranes. Membranes were blocked in Tris buffered saline (TBS) with $5 \%$ dry milk, and incubated with primary antibodies which were followed by either goat anti-mouse conjugated horseradish peroxidase (HRP) (Amersham Biosciences; Piscataway, NJ) or goat anti-rabbit HRP (Cell Signaling Technology; Danvers, MA). Protein bands were detected using chemiluminescent reagent (NEN; Boston,
MA) and a FluorChem E and M Imager (Proteinsimple; San Jose, California).

\section{MALDI-TOF mass spectrometry of full-length aS and $\Delta 71-82$ aS}

Recombinant human full-length $\alpha \mathrm{S}$ and $\Delta 71-82 \alpha \mathrm{S}$ $(\sim 4 \mathrm{mM})$ were diluted to $10 \mu \mathrm{M}$ with $0.1 \%$ TFA (trifluoroacetic acid) solution. $1 \mu$ l diluted sample was mixed with $1 \mu$ l saturated ACCA ( $\alpha$-cyano-4-hydroxycinnamic

A) M20 8 months: fib $\alpha S$

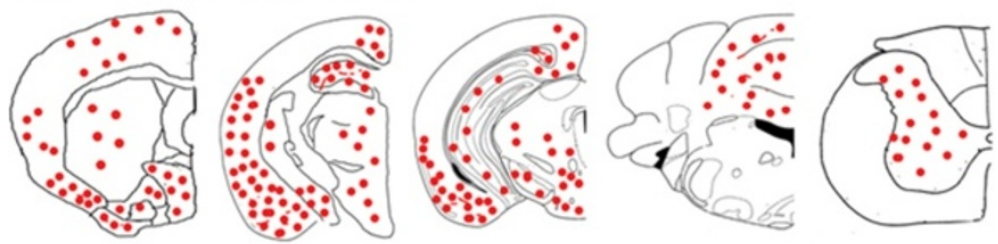

B) M20 8 months: $\Delta 71-82 \alpha S$

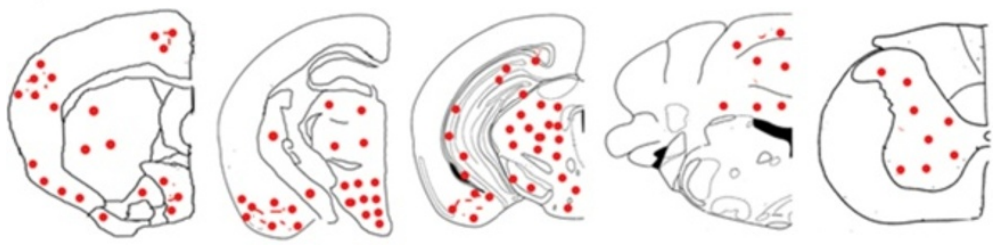

Figure 4 Schematic representation of the distribution of aS pathology at 8 months following brain neonatal injection of 21-140 human aS fibrils or $\Delta \mathbf{7 1 - 8 2}$ human in M20 aS Tg mice. M20 Tg mice injected with $25 \mu \mathrm{g}$ of fibrillar (fib) 21-140 human aS (A) or $\Delta 71-82$ human aS (B). Maps show rostral-caudal distribution of aS inclusions via coronal sections. Equivalent density and distribution of aS pathology was seen bilaterally. Pathology was detected with antibodies pSer129 and Syn506. (A) P0 injection of 21-140 human aS fibrils results in the formation of aS inclusions throughout the cortex, hippocampus, midbrain, brainstem, and spinal cord. (B) P0 injection of $\Delta 71-82$ human aS also results in widespread aS inclusions. The distribution of inclusions was very similar in all mice with pathology. 
acid) solution (acetonitrile: methanol=3:2). $1 \mu$ l sample mixture was loaded to ACCA pretreated MSP 96 target (Bruker Daltonics Inc.; Billerica, MA). The samples were analyzed with a Bruker Microflex (Bruker Daltonics Inc.; Billerica, MA) mass spectrometer in linear positive model. Spectra were calibrated with Bruker protein calibrate standard.

\section{Results}

To further investigate induction of $\alpha \mathrm{S}$ inclusion formation following brain injection of exogenous $\alpha S$ and to generate a higher throughput experimental model, we injected $\mathrm{nTg}$ neonatal mouse brains with exogenous preformed recombinant human $\alpha \mathrm{S}$ amyloid fibrils comprised of 21-140 $\alpha \mathrm{S}$ (Figure 1). We use amino-truncated 21-140 $\alpha \mathrm{S}$, as fibrils comprised of this protein can seed $\alpha \mathrm{S}$ similarly to the full-length protein in cultured cells
$[38,39,41,42]$ and it provides the ability to definitively assess aggregation of the endogenous $\alpha \mathrm{S}$ by detection with amino-terminal specific $\alpha \mathrm{S}$ antibodies. The presence of the exogenous $\alpha \mathrm{S}$ (25 $\mu \mathrm{g}$ injected) could be readily detected in the needle track 2 days post injection in $\mathrm{nTg}$ mouse brains using an antibody to human $\alpha \mathrm{S}$ (Figure 1). By 4 days post-injection, exogenous $\alpha \mathrm{S}$ was not detectable, consistent with the findings recently reported by Masuda-Suzukake and colleagues [21] who also showed exogenous human $\alpha \mathrm{S}$ injected into the brain was detectable only within the first 7 days post injection. We did not detect local or distal induction of intracellular pathology at 4, 8, and 16 days post-injection of $25 \mu \mathrm{g}$ fibrillar $\alpha \mathrm{S}$. Analysis of $\mathrm{nTg}$ mouse brains neonatally injected with $2 \mu \mathrm{g}$ of exogenous fibrillar $21-140 \alpha \mathrm{S}$ and aged up to 8 months did not reveal the presence of any $\alpha S$ pathology (Table 1). Injection of $25 \mu \mathrm{g}$ of exogenous fibrillar

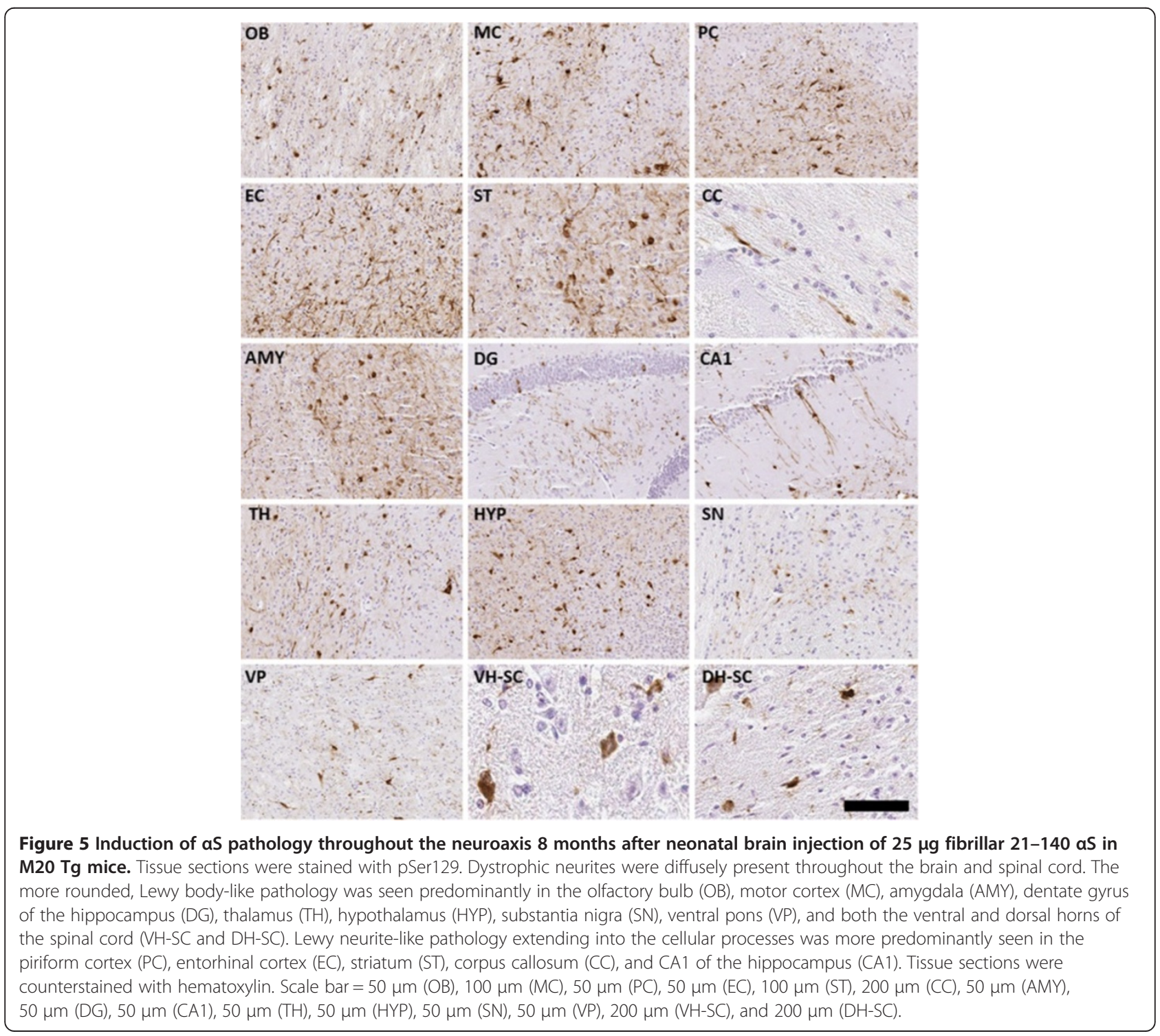


$21-140 \alpha \mathrm{S}$ resulted in rare pathology in only one mouse at 2 months post-injection, but at 8 months postinjection, 4 out of $13 \mathrm{nTg}$ mice injected with this dose of $\alpha S$ showed sparse $\alpha S$ neuronal inclusion pathology primarily localized to cortical neurons (Table 1 and Figure 2). In nTg cohorts injected with either $2 \mu \mathrm{g}$ or $25 \mu \mathrm{g}$ nonamyloidogenic $\Delta 71-82 \alpha \mathrm{S}[34,35,41]$, we did not observe any pathology in nTg mice (see Table 1 ). In these studies $\Delta 71-82 \alpha \mathrm{S}$ was used as a control for conformational templating mechanisms, as we and others have extensively studied this protein and showed that it is deficient in the ability to form or directly affect (induce or inhibit) the formation of $\alpha \mathrm{S}$ amyloid fibrils in vitro or in culture models [34,35,41-43]. After prolonged incubations at high concentrations, $\Delta 71-82 \alpha$-synuclein can form oligomers as observed by negative staining electron microscopy, but these are not amyloidogenic in nature. The $\Delta 71-82 \alpha$-synuclein used for the current studies was not pre-incubated and is in the soluble form as previously described. We have also recently shown that this same preparation of $\Delta 71-82 \alpha-$ synuclein cannot directly seed the formation of $\alpha$-synuclein inclusions in primary neuronal cultures [42]. In contrast the same preparation of fibrillar $\alpha$-synuclein can seed inclusion formation very efficiently in those cultures.

To examine whether overexpression of $\alpha \mathrm{S}$ can increase the efficiency of inclusion pathology formation in vivo, we performed neonatal brain injection of fibrillar 21$140 \alpha \mathrm{S}$ in M20 Tg mice, which overexpress wild type human $\alpha$ S. In adult M20 Tg mice there is $\sim 5$-fold over expression of human $\alpha \mathrm{S}$ in the brain, but these mice do not develop $\alpha S$ pathology during their lifespan in the absence of additional manipulations [31,32]. These mice also overexpress transgenic human $\alpha \mathrm{S}$ during development that can be observed as early as P0 (Figure 3), and as previously reported, the expression of $\alpha \mathrm{S}$ increases during mouse brain development [44]. Thus, they make an ideal model to explore paradigms for induction of $\alpha \mathrm{S}$ pathology. The neonatal brain injection of $2 \mu \mathrm{g}$ fibrillar 21-140 $\alpha \mathrm{S}$ did not induce the formation of intraneuronal pathology at times up to 4 months, but by 8 months sparse cortical pathology could be observed (Table 2). Similar challenge to $\Delta 71-82 \alpha \mathrm{S}$ did not result in the formation of pathology. Increasing the treatment to $25 \mu \mathrm{g}$ fibrillar 21-140 $\alpha \mathrm{S}$ resulted in sparse brain $\alpha \mathrm{S}$ pathology as early as 1 month and 4 months, but it was extensively distributed throughout the neuroaxis by 8 months (Table 2, Figures 4 and 5) at a higher density than in $\mathrm{nTg}$ mice showing $\alpha \mathrm{S}$ pathology at 8 months post-injection of $25 \mu \mathrm{g}$ fibrillar 21-140 $\alpha \mathrm{S}$. Interestingly, $\alpha \mathrm{S}$ inclusions were rarely observed in nigral dopaminergic neurons (Figure 6). Similar to the $\alpha \mathrm{S}$ aggregates in symptomatic M83 Tg mice, which spontaneously develop age-dependent pathology $[31,32]$, the inclusions in M20 Tg mice induced by the brain injection of fibrillar 21-140 $\alpha \mathrm{S}$ were comprised of endogenously expressed $\alpha S$ as they were reactive with amino-terminal specific antibodies Syn506 and SNL-4 (Figures 7 and 8). The inclusions were also reactive with p62 (sequestrosome; Figure 9), a robust marker of $\alpha \mathrm{S}$ inclusions [45]. Unexpectedly, similar brain injection of $\Delta 71-82 \alpha \mathrm{S}$ also resulted in robust and widely distributed $\alpha \mathrm{S}$ brain pathology at 8 months in some of the injected M20 Tg mice (Table 2; Figures 6, 7, 8, 9 and 10). These $\alpha \mathrm{S}$ inclusions were also comprised of endogenous $\alpha S$ (i.e. reactive with antibodies Syn506 and SNL-4) hyperphosphorylated at Ser129, and accumulated p62. For comparison, we show that some of the M20 Tg mice 8 months post-injection with $25 \mu \mathrm{g}$ of $\Delta 71-82 \alpha \mathrm{S}$ are devoid of $\alpha \mathrm{S}$ pathology (see Additional file 1: Figure S1). Although none of the nTg or

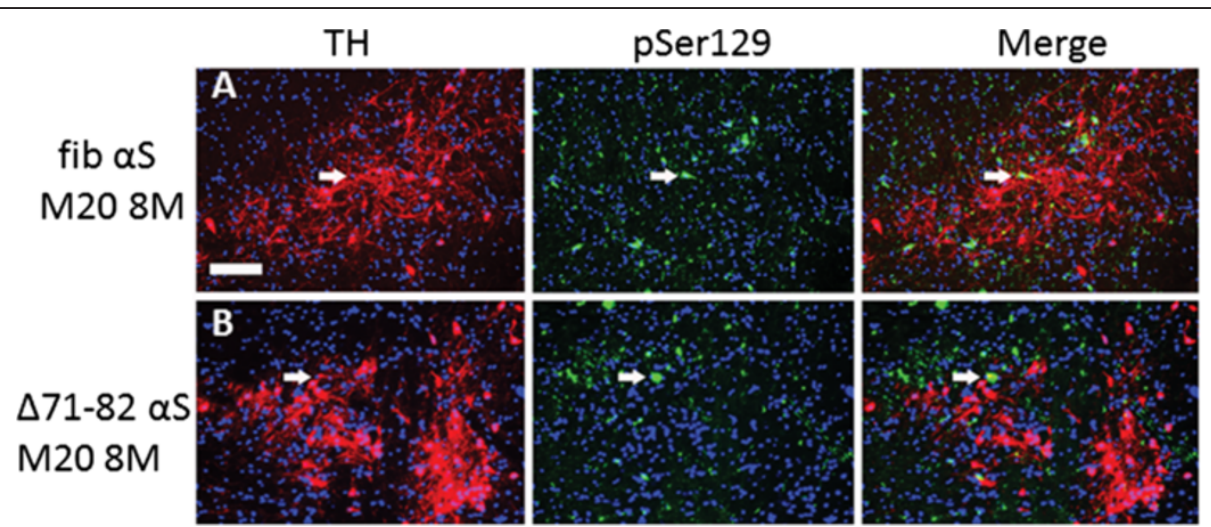

Figure 6 The majority of aS inclusions in the substantia nigra of M20 Tg mice neonatally injected with exogenous aS are not in TH positive neurons. M20 Tg mice 8 months after neonatal injection with 21-140 human aS fibrils (fib) (A) or $\Delta 71-82$ human aS (B). Double-labeled immunofluorescence analysis for tyrosine hydroxylase ( $\mathrm{TH}$; red) labeling the dopaminergic neurons in the substantia nigra area, and pSer129 (green) labeling the hyperphosphorylated as inclusions show minimal co-localization. The majority of as inclusions were not found in $\mathrm{TH}+$ cells, except for a few neurons (white arrows). Cell nuclei were counter stained with DAPI. Scale bar $=100 \mu \mathrm{m}$. 


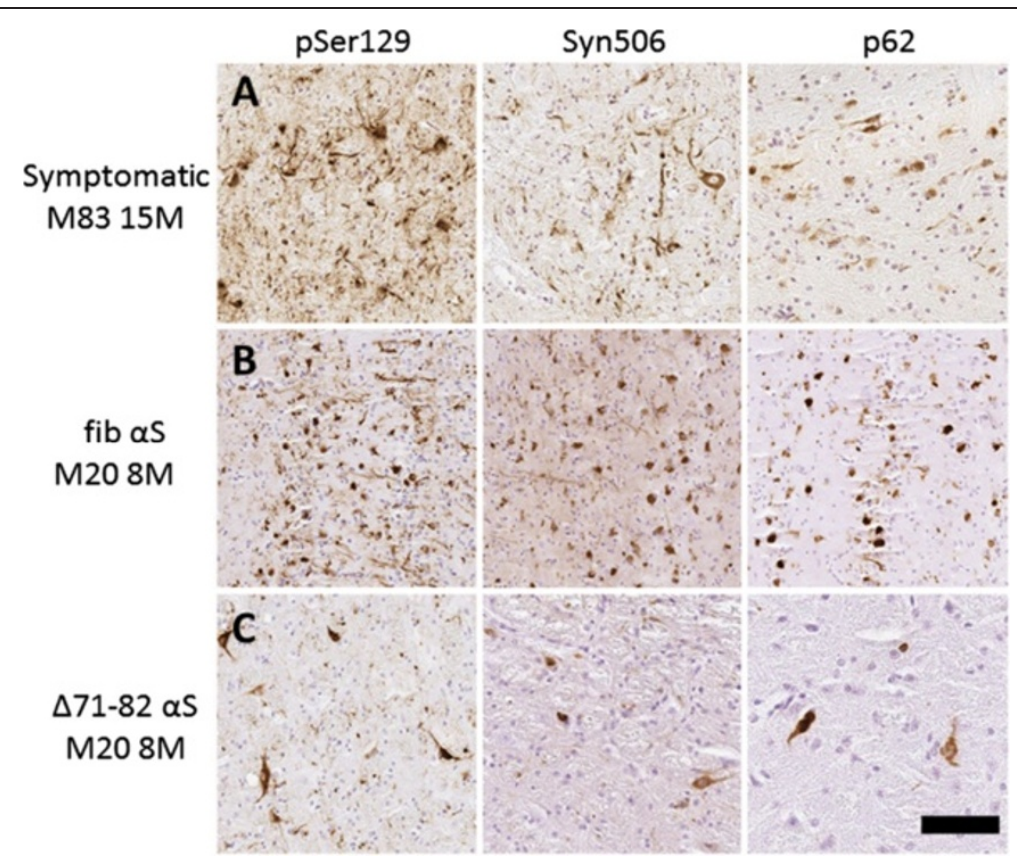

Figure $7 \mathrm{IHC}$ showing similar aS pathology induced by neonatal brain injection of fibrillar human 21-140 aS and $\Delta 71-82$ human aS in M20 Tg mice compared to a symptomatic M83 Tg mouse. Brainstem tissue sections from a 15 month-old symptomatic M83 Tg mouse (A) and 8 month-old M20 Tg mice neonatally injected in the brain with $25 \mu \mathrm{g} 21-140$ fibrillar (fib) aS (B) or $25 \mu \mathrm{g} \Delta 71-82$ (C) show similar staining of aS inclusions as detected with pSer129 by IHC. aS inclusions are also detected with Syn506 and p62 antibodies. Syn506 is a mouse monoclonal antibody that conformationally detects aS inclusions; and p62 is a rabbit polyclonal antibody, which non-specifically recognizes intracellular protein aggregates. Scale bar $=100 \mu \mathrm{m}$.

the M20 Tg mice were extensively analyzed for behavioral changes, the presence of $\alpha \mathrm{S}$ pathological inclusions was not associated with any overt behavioral abnormalities.

To assess if there was an association between neuroinflammation (astrogliosis or microgliosis) and induction of $\alpha \mathrm{S}$ aggregation, tissue sections from all injected
$\mathrm{nTg}$ and M20 Tg mice were stained with antibodies to GFAP and IBA-1. As expected, control untreated M20 Tg mice at 8 months of age showed basal levels of astrocytes and microglia (Figure 11A and $11 \mathrm{H}$ ) [17,32]. Most injected $\mathrm{nTg}$ and M20 Tg mice at 1, 2 or 4 month post-injection did not display increased astrogliosis or microgliosis as

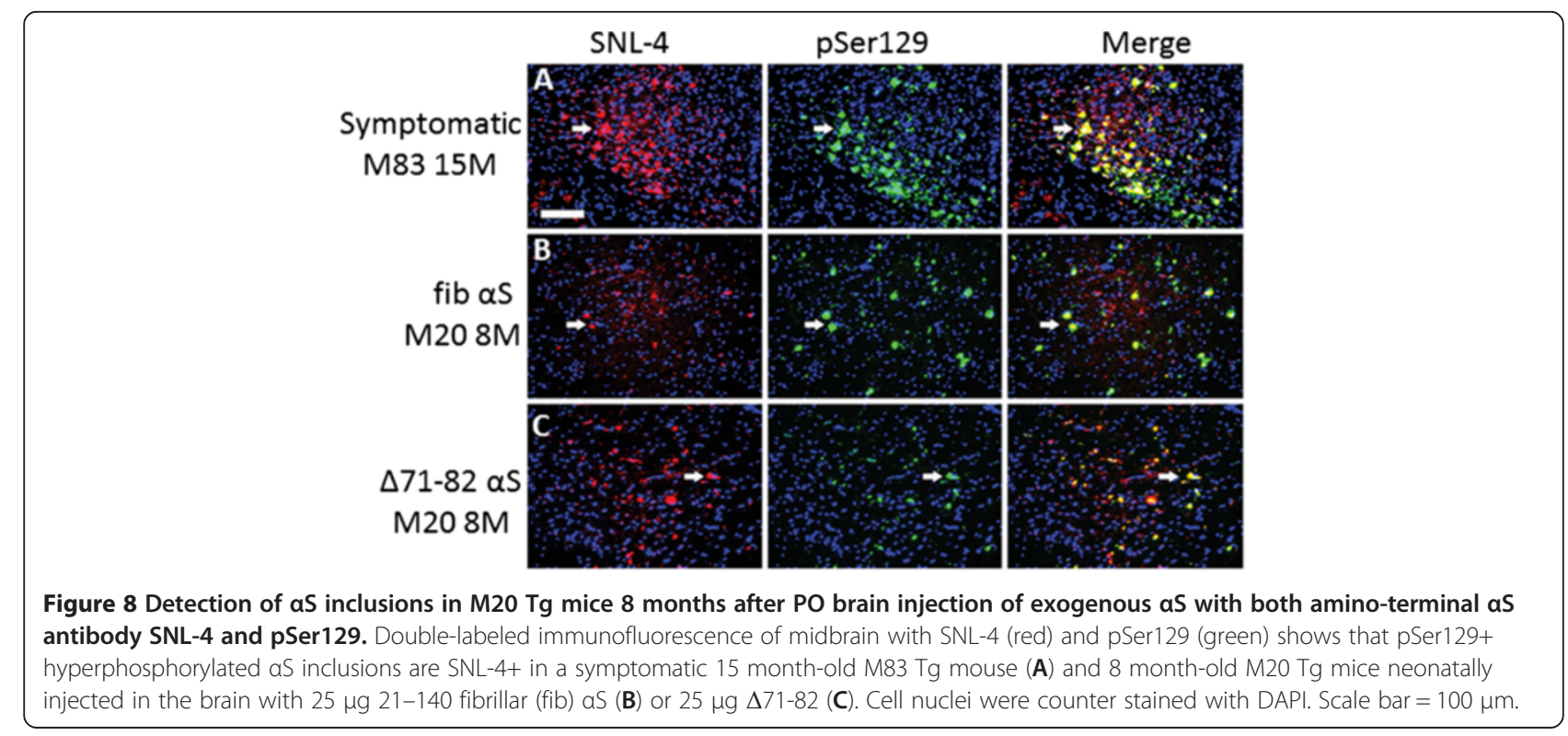




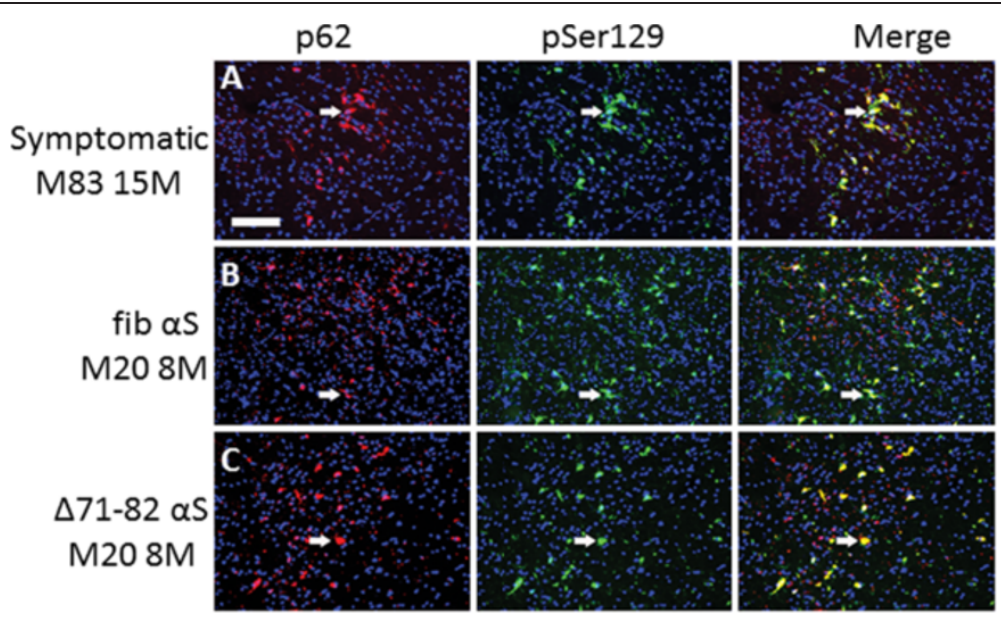

Figure 9 Co-localization of p62 with aS inclusions in 8 month-old M20 Tg mice following neonatal brain injection of exogenous aS. Double-labeled immunofluorescence analysis in the midbrain region for p62 (red) and pSer129 (green) showing that most pSer129+ hyperphosphorylated aS inclusions are p62+ in a symptomatic 15 month-old M83 Tg mouse (A) and 8 month-old M20 Tg mice neonatally injected in the brain with $25 \mu \mathrm{g}$ 21-140 fibrillar (fib) aS (B) or $25 \mu \mathrm{g} \Delta 71-82$ (C). Cell nuclei were counter stained with DAPI. Scale bar $=100 \mu \mathrm{m}$.

shown for M20 Tg mice 2 months post-injection with $25 \mu \mathrm{g}$ fibrillar $\alpha \mathrm{S}$ (Figure 11B and 11I). At these ages some of the M20 Tg mice with or without brain $\alpha \mathrm{S}$ pathology also revealed a modest increase in astrogliosis. In 8 month old nTg mice injected with fibrillar $\alpha \mathrm{S}$ and with modest $\alpha \mathrm{S}$ pathology, only minimal induction of astrocytes and microglia was observed (Figure 11C, 11D, 11J and 11K). Conversely, in 8 month old M20 Tg mice with significant $\alpha \mathrm{S}$ pathology induced by neonatal injection of $25 \mu \mathrm{g}$ fibrillar $\alpha \mathrm{S}$, robust astrogliosis and modest microgliosis were observed (Figure 11E, 11L). Furthermore, in 8 month old M20 Tg mice injected with $25 \mu \mathrm{g} \Delta 71-82 \alpha \mathrm{S}$, there was also robust astrogliosis (Figure 11F, 11G, 11M, and $11 \mathrm{~N})$ regardless of whether $\alpha \mathrm{S}$ pathology had developed. These findings indicate that treatment with fibrillar or non-amyloidogenic $\alpha \mathrm{S}$ can induce a delayed activation of neuroinflammation that is significantly accentuated in M20 $\mathrm{Tg}$ mice relative to $\mathrm{nTg}$ mice.

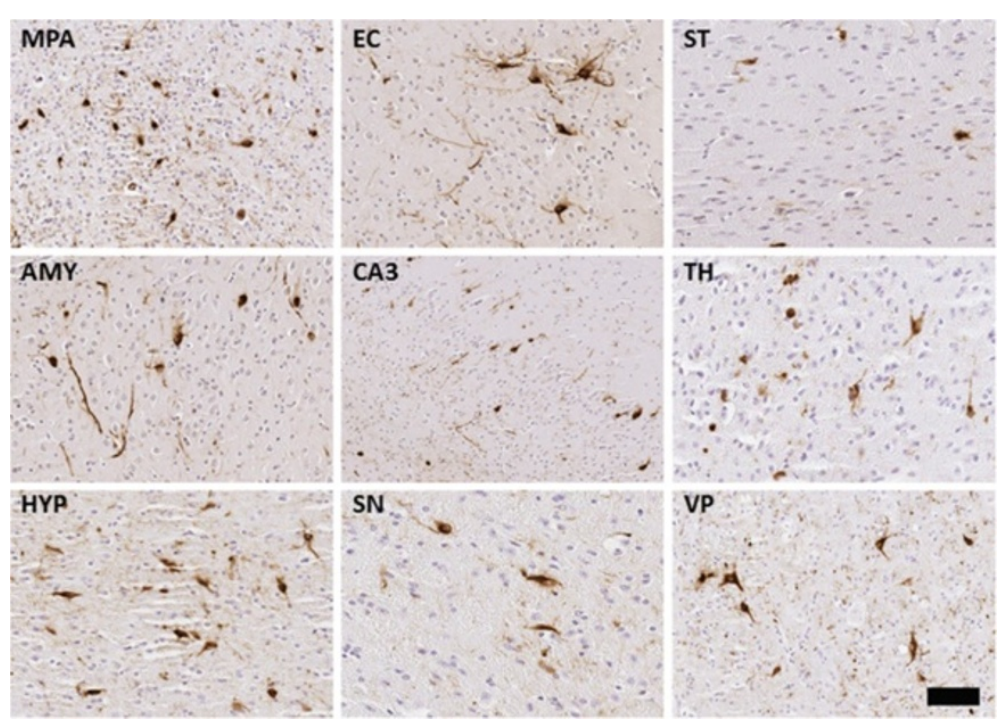

Figure 10 Induction of aS pathology throughout the neuroaxis 8 months after neonatal brain injection of 25 $\mu \mathrm{g} \Delta 71-82$ aS in M20 Tg mice. Tissue sections were stained with pSer129. Round perikaryal inclusions and dystrophic neurites were diffusely spread throughout the brain and spinal cord. The more rounded, Lewy body-like pathology was seen predominantly in the medial preoptic area (MPA), striatum (ST), thalamus $(T H)$, hypothalamus (HYP), substantia nigra (SN), and ventral pons (VP). Lewy neurite-like pathology extending into the cellular processes was more predominantly seen in the entorhinal cortex (EC), amygdala (AMY), and CA3 region of the hippocampus (CA3). Tissue sections were counterstained with hematoxylin. Scale bars $=100 \mu \mathrm{m}$ (MPA), $50 \mu \mathrm{m}$ (EC), $100 \mu \mathrm{m}$ (ST), $100 \mu \mathrm{m}$ (AMY), $200 \mu \mathrm{m}$ (CA3), $50 \mu \mathrm{m}$ (TH), $100 \mu \mathrm{m}$ (HYP), $50 \mu \mathrm{m}(\mathrm{SN})$, and $100 \mu \mathrm{m}(\mathrm{VP})$. 


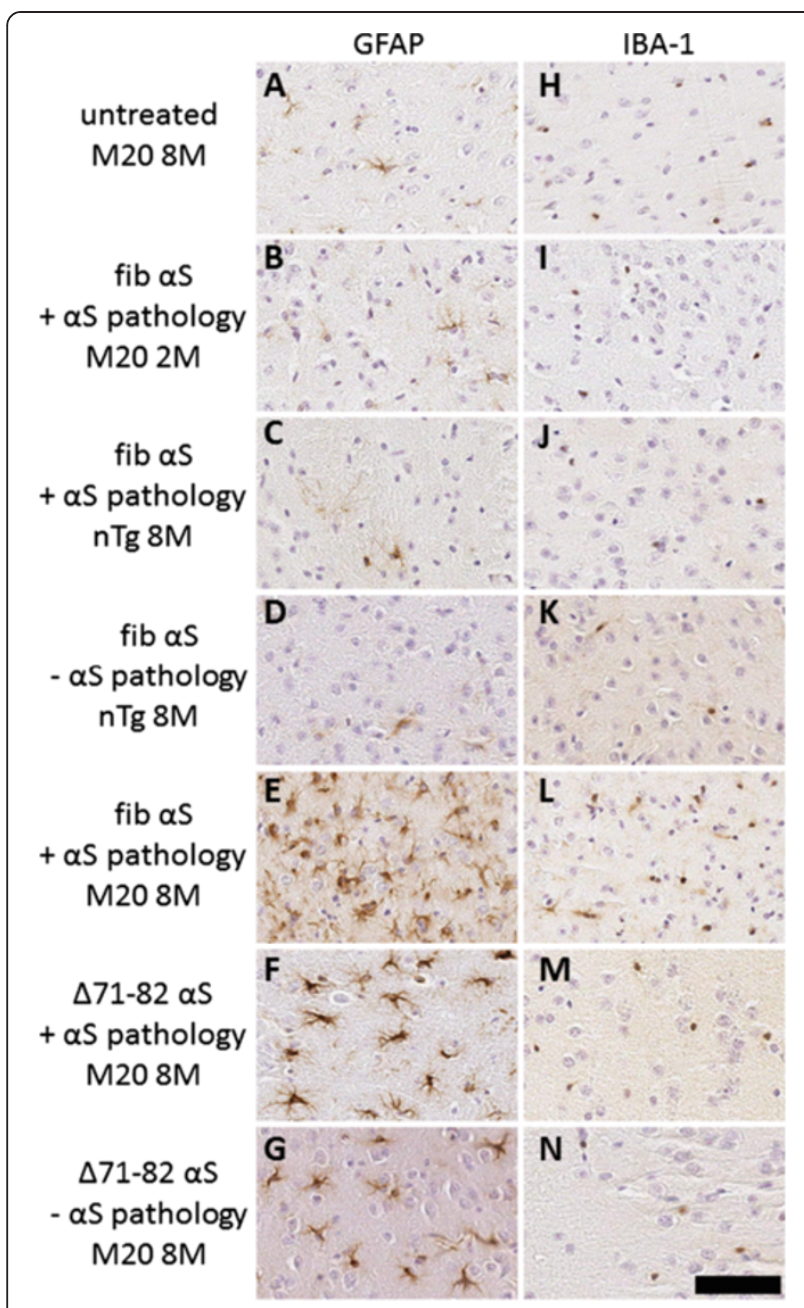

Figure 11 Delayed induction of astrogliosis and microgliosis in mice neonatally injected with soluble $\Delta 71-82$ aS or fibrillar aS at 8 months post-injection. Tissue sections were stained with GFAP antibody (A-G), which detects astrocytes, and IBA-1 antibody (H-N), which detects microglia. Representative images were taken of the entorhinal cortex, where a high density of as pathology tends to form due to neonatal injection (see Figures 2, 4, 5 and 10). An 8-month-old control untreated M20 Tg mouse $(\mathbf{A}, \mathbf{H})$ and a M20 Tg mouse injected with $25 \mu \mathrm{g}$ of 21-140 fibrillar (fib) aS at 2 months post-injection (B, I) show basal levels of astrocytes and microglia. There was no significant increase from basal levels in the brains of a $\mathrm{nTg}$ mouse with pathology $(\mathbf{C}, \mathbf{J})$ relative to a similar $\mathrm{nTg}$ mouse without pathology $(\mathbf{D}, \mathbf{K})$ at 8 months post-injection of $25 \mu \mathrm{g}$ of 21-140 fibrillar aS. Robust astrocyte and microglia activation as observed 8 months after injection in M20 Tg mice with brain aS pathology treated with $25 \mu \mathrm{g}$ of 21-140 fibrillar aS (E, L). In addition, robust astrogliosis was also observed in M20 Tg mice 8 months after injection of $25 \mu \mathrm{g}$ of $\Delta 71-82$ aS with $(\mathbf{F}, \mathbf{M})$, or without $(\mathbf{G}, \mathbf{N})$ brain aS pathology. Tissue sections were counterstained with hematoxylin. Scale bar $=50 \mu \mathrm{m}$.

To evaluate the purity, biophysical properties, and integrity of the recombinant $\Delta 71-82 \alpha \mathrm{S}$, we performed MS analysis (Figure 12). We confirmed by K114 fluorometry that $\Delta 71-82 \alpha \mathrm{S}$ protein was not amyloidogenic as previously described [35], and that the addition of exogenous
$\Delta 71-82 \alpha \mathrm{S}$ could not induce $\alpha \mathrm{S}$ inclusion formation in cultured cells [42].

\section{Discussion and conclusion}

Our studies demonstrate that the brain injection of exogenous $\alpha \mathrm{S}$ can induce intraneuronal $\alpha \mathrm{S}$ pathology after prolonged incubation times. Within days the injected $\alpha \mathrm{S}$ is rapidly cleared and the inclusion pathology that arises from endogenously expressed $\alpha \mathrm{S}$ takes months to form. These findings are consistent with those of MasudaSuzukake and colleagues who showed that exogenously injected human $\alpha \mathrm{S}$ fibrils $(10 \mu \mathrm{g})$ into the brains of $\mathrm{nTg}$ mice can be detected for less than 1 week, but induction of $\alpha \mathrm{S}$ pathology is observed 3 months later [21]. All prior studies of intraneuronal induction of $\alpha \mathrm{S}$ by cerebral challenge to exogenous fibrils have been interpreted as being indicative of a "prion-like" spread of $\alpha \mathrm{S}$ pathology $[18,20,21]$. Indeed the delayed induction of $\alpha S$ pathology by exogenous $\alpha S$ observed here and by Masuda-Suzukake et al. [21] may be interpreted as stable $\alpha \mathrm{S}$ seeds that are present below detectable levels. Over time these seeds induce pathology, which then may spread via a cycle of inclusion pathology giving rise to additional nucleation events that can be spread from cell to cell. Our findings that an injection of a non-amyloidogenic form of $\alpha S(\Delta 71-82)$ can induce similar delayed pathology indicate that it may be premature to conclude that the pathology induced is solely attributable to conformational dependent templating events. In both the Masuda-Suzukake et al. [21] and Luk et al. [20] studies using $n T g$ mice, soluble $\alpha \mathrm{S}$ was injected as controls and no induction of pathology was reported. As we find that at a higher dose of $\alpha \mathrm{S}$ there is more robust induction of $\alpha \mathrm{S}$ pathology both in terms of extent of pathology and time to onset of pathology induction, and that injection of $\alpha \mathrm{S}$ in M20 Tg mice also enhances the resultant inclusion pathology phenotype, it is possible that the lower doses $(5-10 \mu \mathrm{g})$ of injected soluble $\alpha \mathrm{S}$ in those studies $[20,21]$ may account for the lack of pathology induction reported. Notably, a soluble $\alpha \mathrm{S}$ control injection was not reported in the study demonstrating pathology induction in adult M83 $\mathrm{Tg}$ mice [18]. Here using neonatal $\alpha \mathrm{S} \mathrm{Tg}$ mice, we observed that injection of soluble $\Delta 71-82 \alpha \mathrm{S}$ is capable of inducing $\alpha \mathrm{S}$ pathology similar to amyloidogenic $\alpha \mathrm{S}$. Induction of robust intraneuronal $\alpha \mathrm{S}$ pathology by exogenous $\Delta 71-82 \alpha S$ challenge does not appear to be attributable to the neonatal injection paradigm as we have observed similar findings in adult mice (Sacino et al., in preparation). The finding that M20 $\mathrm{Tg}$ mice are more prone to inclusion formation resulting from treatment with either exogenous fibrillar $\alpha \mathrm{S}$ or soluble $\Delta 71-82 \alpha \mathrm{S}$ is likely due to a dosage effect of $\alpha \mathrm{S}$ expression, which could be akin to patients with duplication or triplication of the SNCA gene. Although the cohorts of mice used here are not large, they are comparable to those used by others to 


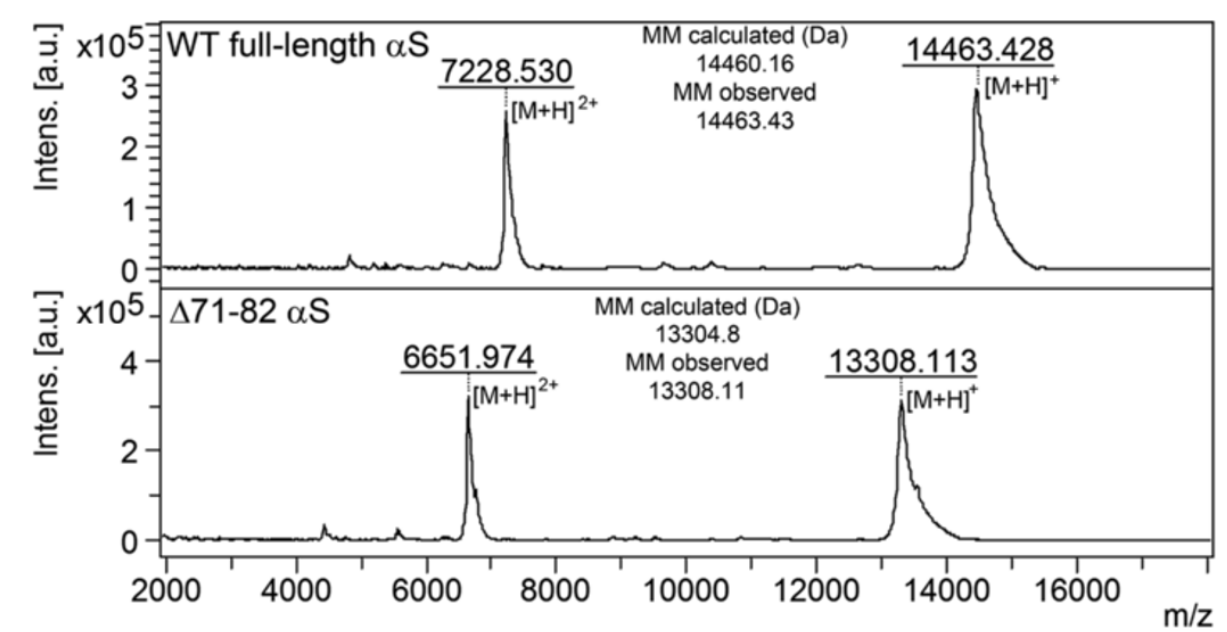

Figure 12 Mass spectrometric analysis of the $\Delta 71-82$ aS used for neonatal brain injection. To verify that $\Delta 71-82$ aS was the correct protein and its integrity, we performed mass spectrometry and compared the molecular mass to full length aS. Up panel, recombinant full-length human aS wild type; bottom panel, recombinant human $\Delta 71-82$ aS.

study the induction of brain pathology using injected exogenous $\alpha \mathrm{S}[18,20,21]$. Larger cohorts of mice injected with various dosages of $\alpha \mathrm{S}$ are currently being aged to longer time points to further understand the mechanisms involved in exogenous $\alpha \mathrm{S}$ induction of brain pathology.

Circumstantial evidence from post-mortem studies of the distribution of $\alpha S$ pathology in the brains of PD patients as well as the induction of $\alpha S$ pathology in transplanted neurons in the brains of some PD patients has been used to support the hypothesis that $\alpha \mathrm{S}$ pathology may spread from cell-to-cell by a "prion-like" mechanism $[13,14,46-48]$. However, many alternative explanations including chronic neuroinflammation, oxidative stress triggered by excitotoxicity, and loss of homeostasis from cellular stress, may lead to the failure of molecular chaperones and other machinery to effectively control the level of misfolded $\alpha \mathrm{S}$ [22-25].

Our data that soluble non-amyloidogenic $\alpha \mathrm{S}$ can induce widespread $\alpha \mathrm{S}$ pathology raises questions regarding the "prion-like" spread of pathology that has been reported, but it is premature to conclude that our studies definitively refute that mechanism. It is plausible that in the brain a non-amyloidogenic $\alpha \mathrm{S}$ could be converted into amyloidogenic seeds through additional modifications or interactions with lipids or protein chaperones. Thus, studies that track the fate of injected exogenous $\alpha S$ will be necessary to evaluate these possibilities.

Alternatively, these studies do strongly suggest that other mechanism(s) of induction of pathology by exogenous $\alpha \mathrm{S}$ should be considered. For example, there are extensive reports on how extracellular $\alpha \mathrm{S}$ can lead to activation of the innate immune response via toll-like receptor pathways akin to lipopolysaccharide activation [49-62], and single intracerebellar or intraperitoneal injections of lipopolysaccharide have been shown to result in the long-lasting induction of $\alpha \mathrm{S}$ neuronal inclusion formation [63,64]. Importantly, $\alpha S$ lacking residues 71-82 has been shown to induce inflammation similar to full-length $\alpha \mathrm{S}$ [54,59]. In our current study, we have observed a delayed, long-term activation of neuroinflammation induced by brain treatment to both soluble and fibrillar $\alpha \mathrm{S}$ that is accentuated in M20 Tg mice compared to $\mathrm{nTg}$ mice. These findings are consistent with cell culture studies that showed that both soluble and aggregated $\alpha S$ are potent activators of inflammation [49-62]. It is possible that the exogenous treatment of $\alpha \mathrm{S}$ may trigger a slow positive feedback loop of inflammation and secretion followed by aggregation that may require a certain threshold of inflammation that builds overtime. Therefore, some of the M20 Tg mice with neuroinflammation, but without $\alpha \mathrm{S}$ inclusions 8 months after treatment with $\Delta 71$ $82 \alpha \mathrm{S}$ may not yet have reached the necessary threshold. Exogenous $\Delta 71-82 \alpha \mathrm{S}$ may not be as potent an inducer of this process as is fibrillar $\alpha \mathrm{S}$, because it may have a shorter half-life than aggregated $\alpha S$, which could explain why it was not as potent as fibrillar $\alpha S$; however, this possibility will be investigated in future studies. However, the hypothesis that inflammation may play an important role in the spread of $\alpha \mathrm{S}$ pathology induced by exogenous $\alpha \mathrm{S}$ is only one of several possible mechanisms that may act synergistically or independently to promote the spread of $\alpha \mathrm{S}$ pathology [22-25].

Furthermore, there is abundant evidence that prionoid self-protein aggregates represent what are referred to immunologically as Danger Associated Molecular Patterns (DAMPs) and are capable of inducing robust immune responses [65]. A number of studies show that when prionoids associated with CNS proteinopathies are applied 
exogenously to glial cells they can activate innate immunity through pattern recognition receptors (PRR) and induce a proinflammatory response [65-68]. This innate immune response in turn could trigger inclusion pathology. Notably, these mechanisms are not mutually exclusive and may be mutually self-reinforcing [25]. Our impression from these studies is that amyloidogenic $\alpha \mathrm{S}$ is a more efficient inducer of pathology than the non-amyloidogenic $\alpha \mathrm{S}$. This differential efficiency could be attributed to a myriad of different properties ranging from stability of the aggregated $\alpha \mathrm{S}$, differential ability to template pathology, immunogenicity, or some combination of these factors.

Our recent studies in cultured cell provide strong evidence that amyloidogenic conformational templating of $\alpha S$ can readily occur under certain conditions [42], but the situation in vivo is likely more complex and aggregate formation can involve several mechanisms. To this point, treatment with $\Delta 71-82 \alpha \mathrm{S}$ did not induce $\alpha \mathrm{S}$ aggregation in cultured cells, while fibrillar $\alpha \mathrm{S}$ was able to readily do so. A limitation of studies in culture cells is the duration of time (a few weeks) that the cells can be maintained experimentally, which may not be efficient to study mechanisms that are slower and more progressive. Collectively these data indicate that exposure to exogenous $\alpha \mathrm{S}$ can induce intracellular aggregate formation by at least 2 mechanisms that are not mutually exclusive and could likely be synergistic.

Further studies will be needed to determine the relative contribution of "prion-like" protein self-templating versus other mechanisms in the induction and propagation of $\alpha \mathrm{S}$ pathology. Notably, the neonatal injection paradigm that we have developed can accelerate these mechanistic studies by reducing the time needed to establish cohorts of mice necessary to conduct those studies. As nonamyloidogenic $\alpha \mathrm{S}$ can induce $\alpha \mathrm{S}$ pathology similar to fibrillar amyloidogenic $\alpha \mathrm{S}$, it is possible that any form of brain injury that promotes release of normal cellular $\alpha S$ could trigger intraneuronal $\alpha \mathrm{S}$ pathology. Extracellular $\alpha \mathrm{S}$ release could also occur during neurodegeneration when neurons die and this could be exacerbated if the protein is not cleared rapidly. More definitive elucidation of the mechanism(s) that underlie induction and spread of $\alpha \mathrm{S}$ pathology are likely to provide key insights into ongoing efforts designed to target $\alpha \mathrm{S}$ in vivo and thereby ultimately lead to novel disease modifying therapies for PD and other $\alpha$-synucleinopathies.

\section{Additional file}

Additional file 1: Figure S1. Lack of induction of aS pathology throughout the neuroaxis 8 months after neonatal brain injection of $25 \mu \mathrm{g} \Delta \mathbf{7 1 - 8 2}$ aS in M20 Tg mice. Tissue sections were stained with pSer129. Brain regions that typically showed Lewy body/neurite-like pathology after injection of $25 \mu \mathrm{g} \Delta 71-82$ aS in M20 Tg mice, were blank in an unaffected mouse: the medial preoptic area (MPA), striatum (ST), thalamus (TH), hypothalamus (HYP), substantia nigra (SN), ventral pons (VP), entorhinal cortex (EC), amygdala (AMY), and CA3 region of the

hippocampus (CA3). Tissue sections were counterstained with hematoxylin. Scale bars $=100 \mu \mathrm{m}$ (MPA), $50 \mu \mathrm{m}$ (EC), $100 \mu \mathrm{m}$ (ST), $100 \mu \mathrm{m}$ (AMY), $200 \mu \mathrm{m}$ (CA3), $50 \mu \mathrm{m}(\mathrm{TH})$,

$100 \mu \mathrm{m}$ (HYP), $50 \mu \mathrm{m}$ (SN), and $100 \mu \mathrm{m}$ (VP).

\section{Competing interest}

The authors declare that they have no conflict of interest.

\section{Authors' contributions}

ANS designed the study, performed the injections, analyzed the data, and drafted the manuscript. MB collected the samples and analyzed the data. $\mathrm{NHM}$ analyzed the data. ABM performed the injections and analyzed the data. MAT performed the injections and analyzed the data. YL participated in coordination of study. YR participated in the design of the study and performed the mass spectrometric analysis. TEG and BIG participated in the design and coordination of the study, analyzed the data, and helped to draft the manuscript. All authors read and approved the final manuscript.

\section{Acknowledgements}

This work was supported by the Ellison Medical Foundation Senior Scholar Award to TEG and funding from the University of Florida.

Received: 10 July 2013 Accepted: 10 July 2013

Published: 17 July 2013

\section{References}

1. Waxman EA, Giasson BI: Molecular mechanisms of alpha-synuclein neurodegeneration. Biochim Biophys Acta 2008, 1792:616-624.

2. Goedert M: Familial Parkinson's disease, The awakening of alphasynuclein. Nature 1997, 388(6639):232-233.

3. Cookson MR: The biochemistry of Parkinson's disease. Annu Rev Biochem 2005, 74:29-52.

4. Polymeropoulos MH, Lavedan C, Leroy E, et al: Mutation in the alphasynuclein gene identified in families with Parkinson's disease. Science 1997, 276(5321):2045-2047.

5. Kruger R, Kuhn W, Muller T, et al: Ala30Pro mutation in the gene encoding alpha-synuclein in Parkinson's disease. Nat Genet 1998, 18(2):106-108.

6. Zarranz JJ, Alegre J, Gomez-Esteban JC, et al: The new mutation, E46K, of alpha-synuclein causes Parkinson and Lewy body dementia. Ann Neurol 2004, 55(2):164-173.

7. Farrer M, Kachergus J, Forno L, et al: Comparison of kindreds with parkinsonism and alpha-synuclein genomic multiplications. Ann Neurol 2004, 55(2):174-179.

8. Singleton $A B$, Farrer $M$, Johnson J, et al: Alpha-Synuclein locus triplication causes Parkinson's disease. Science 2003, 302(5646):841.

9. Kiely AP, Asi YT, Kara E, et al: alpha-Synucleinopathy associated with G51D SNCA mutation: a link between Parkinson's disease and multiple system atrophy? Acta Neuropathol 2013, 125(5):753-769.

10. Proukakis C, Dudzik CG, Brier T, et al: A novel alpha-synuclein missense mutation in Parkinson disease. Neurology 2013, 80(11):1062-1064.

11. Lesage S, Anheim M, Letournel F, et al: G51D alpha-synuclein mutation causes a novel parkinsonian-pyramidal syndrome. Ann Neurol 2013: in press (on-line).

12. Goldberg MS, Lansbury PT: Is there a cause-and-effect relationship between alpha-synuclein fibrillization and Parkinson's disease? Nat Cell Biol 2000, 2(7):E115-E119.

13. Kordower JH, Chu Y, Hauser RA, Freeman TB, Olanow CW: Lewy body-like pathology in long-term embryonic nigral transplants in Parkinson's disease. Nat Med 2008, 14(5):504-506.

14. Li JY, Englund $E$, Holton JL, et al: Lewy bodies in grafted neurons in subjects with Parkinson's disease suggest host-to-graft disease propagation. Nat Med 2008, 14(5):501-503.

15. Li JY, Englund $\mathrm{E}$, Widner $\mathrm{H}$, et al: Characterization of Lewy body pathology in 12- and 16-year-old intrastriatal mesencephalic grafts surviving in a patient with Parkinson's disease. Mov Disord 2010, 25(8):1091-1096.

16. Braak H, Bohl JR, Muller CM, Rub U, De Vos RA, Del TK: Stanley Fahn Lecture 2005: the staging procedure for the inclusion body pathology 
associated with sporadic Parkinson's disease reconsidered. Mov Disord 2006, 21(12):2042-2051.

17. Giasson BI, Duda JE, Quinn SM, Zhang B, Trojanowski JQ, Lee VM: Neuronal alpha-synucleinopathy with severe movement disorder in mice expressing A53T human alpha-synuclein. Neuron 2002, 34(4):521-533.

18. Luk KC, Kehm VM, Zhang B, O'Brien P, Trojanowski JQ, Lee VM: Intracerebral inoculation of pathological alpha-synuclein initiates a rapidly progressive neurodegenerative alpha-synucleinopathy in mice. J Exp Med 2012, 209(5):975-986.

19. Mougenot AL, Nicot S, Bencsik A, et al: Prion-like acceleration of a synucleinopathy in a transgenic mouse model. Neurobiol Aging 2012, 33(9):2225-2228

20. Luk KC, Kehm V, Carroll J, et al: Pathological alpha-synuclein transmission initiates Parkinson-like neurodegeneration in nontransgenic mice. Science 2012, 338(6109):949-953.

21. Masuda-Suzukake M, Nonaka T, Hosokawa M, et al: Prion-like spreading of pathological alpha-synuclein in brain. Brain 2013, 136(Pt 4):1128-1138.

22. Brundin P, Li JY, Holton JL, Lindvall O, Revesz T: Research in motion: the enigma of Parkinson's disease pathology spread. Nat Rev Neurosci 2008, 9(10):741-745

23. Sacino AN, Giasson Bl: Does a prion-like mechanism play a major role in the apparent spread of alpha-synuclein pathology? Alzheimers Res Ther 2012, 4(6):48.

24. Lema Tome CM, Tyson T, Rey NL, Grathwohl S, Britschgi M, Brundin P: Inflammation and alpha-synuclein's prion-like behavior in parkinson's disease-is there a link? Mol Neurobiol 2012, 47(2):561-574.

25. Golde TE, Borchelt DR, Giasson BI, Lewis J: Thinking laterally about neurodegenerative proteinopathies. J Clin Invest 2013, 123(5):1847-1855.

26. Waxman EA, Giasson Bl: Specificity and regulation of casein kinasemediated phosphorylation of alpha-synuclein. J Neuropathol Exp Neurol 2008, 67(5):402-416.

27. Giasson Bl, Jakes R, Goedert M, et al: A panel of epitope-specific antibodies detects protein domains distributed throughout human alpha-synuclein in Lewy bodies of Parkinson's disease. J Neurosci Res 2000, 59(4):528-533.

28. Baba M, Nakajo S, Tu PH, et al: Aggregation of alpha-synuclein in Lewy bodies of sporadic Parkinson's disease and dementia with Lewy bodies. Am J Pathol 1998, 152(4):879-884.

29. Duda JE, Giasson BI, Mabon ME, Lee VMY, Trojanoswki JQ: Novel antibodies to oxidized a-synuclein reveal abundant neuritic pathology in Lewy body disease. Ann Neurol 2002, 52:205-210.

30. Waxman EA, Duda JE, Giasson BI: Characterization of antibodies that selectively detect alpha-synuclein in pathological inclusions. Acta Neuropathol 2008, 116(1):37-46.

31. Giasson BI, Duda JE, Quinn SM, Zhang B, Trojanoswki JQ, Lee VMY: Neuronal a-synucleinopathy with severe movement disorder in mice expressing A53T human a-synuclein. Neuron 2002, 34:521-533.

32. Emmer KL, Waxman EA, Covy JP, Giasson BI: E46K human alpha-synuclein transgenic mice develop Lewy-like and tau pathology associated with age-dependent, detrimental motor impairment. J Biol Chem 2011, 286(40):35104-35118.

33. Chakrabarty P, Ceballos-Diaz C, Beccard A, et al: IFN-gamma promotes complement expression and attenuates amyloid plaque deposition in amyloid beta precursor protein transgenic mice. J Immunol 2010, 184(9):5333-5343.

34. Giasson Bl, Murray IV, Trojanowski JQ, Lee VMY: A hydrophobic stretch of 12 amino acid residues in the middle of alpha- synuclein is essential for filament assembly. J Biol Chem 2001, 276:2380-2386.

35. Waxman EA, Mazzulli JR, Giasson Bl: Characterization of hydrophobic residue requirements for alpha-synuclein fibrillization. Biochemistry 2009, 48(40):9427-9436

36. Greenbaum EA, Graves CL, Mishizen-Eberz AJ, et al: The E46K mutation in alpha -synuclein increases amyloid fibril formation. J Biol Chem 2005, 280(9):7800-7807.

37. Crystal AS, Giasson Bl, Crowe A, et al: A comparison of amyloid fibrillogenesis using the novel fluorescent compound K114. J Neurochem 2003, 86(6):1359-1368.

38. Waxman EA, Giasson Bl: A novel, high-efficiency cellular model of fibrillar alpha-synuclein inclusions and the examination of mutations that inhibit amyloid formation. J Neurochem 2010, 113(2):374-388.
39. Waxman EA, Giasson BI: Characterization of kinases involved in the phosphorylation of aggregated alpha-synuclein. J Neurosci Res 2011 89(2):231-247

40. Duda JE, Giasson BI, Gur TL, et al: Immunohistochemical and biochemical studies demonstrate a distinct profile of alpha-synuclein permutations in multiple system atrophy. $J$ Neuropathol Exp Neurol 2000, 59(9):830-841

41. Luk KC, Song C, O'Brien P, et al: Exogenous alpha-synuclein fibrils seed the formation of Lewy body-like intracellular inclusions in cultured cells. Proc Natl Acad Sci USA 2009, 106(47):20051-20056.

42. Sacino AN, Thomas MA, Ceballos-Diaz C, et al: Conformational templating of alpha-synuclein aggregates in neuronal-glial cultures.

Mol Neurodegener 2013, 8:17

43. Zibaee S, Jakes R, Fraser G, Serpell LC, Crowther RA, Goedert M: Sequence determinants for amyloid fibrillogenesis of human alpha-synuclein. J Mol Biol 2007, 374(2):454-464

44. Hsu LJ, Mallory M, Xia Y, et al: Expression pattern of synucleins (non-Abeta component of Alzheimer's disease amyloid precursor protein/alphasynuclein) during murine brain development. J Neurochem 1998, 71(1):338-344

45. Kuusisto E, Parkkinen L, Alafuzoff I: Morphogenesis of Lewy bodies: dissimilar incorporation of alpha-synuclein, ubiquitin, and p62. J Neuropathol Exp Neurol 2003, 62(12):1241-1253.

46. Mendez I, Vinuela A, Astradsson A, et al: Dopamine neurons implanted into people with Parkinson's disease survive without pathology for 14 years. Nat Med 2008, 14(5):507-509.

47. Braak H, Rub U, Gai WP, Del TK: Idiopathic Parkinson's disease: possible routes by which vulnerable neuronal types may be subject to neuroinvasion by an unknown pathogen. J Neural Transm 2003, 110(5):517-536

48. Braak H, Del Tredici K, Rub U, De Vos RA, Jansen Steur EN, Braak E: Staging of brain pathology related to sporadic Parkinson's disease. Neurobiol Aging 2003, 24(2):197-211.

49. Roodveldt C, Christodoulou J, Dobson CM: Immunological features of alphasynuclein in Parkinson's disease. J Cell Mol Med 2008, 12(5B):1820-1829.

50. Su X, Maguire-Zeiss KA, Giuliano R, Prifti L, Venkatesh K, Federoff HJ: Synuclein activates microglia in a model of Parkinson's disease. Neurobiol Aging 2008, 29(11):1690-1701.

51. Zhang W, Wang T, Pei Z, et al: Aggregated alpha-synuclein activates microglia: a process leading to disease progression in Parkinson's disease. FASEB J 2005, 19(6):533-542.

52. Klegeris A, Giasson Bl, Zhang H, Maguire J, Pelech S, McGeer PL: Alphasynuclein and its disease-causing mutants induce ICAM-1 and IL-6 in human astrocytes and astrocytoma cells. FASEB J 2006, 20(12):2000-2008.

53. Tansey MG, Goldberg MS: Neuroinflammation in Parkinson's disease: its role in neuronal death and implications for therapeutic intervention. Neurobiol Dis 2010, 37(3):510-518.

54. Klegeris A, Pelech S, Giasson Bl, et al: Alpha-synuclein activates stress signaling protein kinases in THP-1 cells and microglia. Neurobiol Aging 2008, 29(5):739-752.

55. Reynolds AD, Glanzer JG, Kadiu I, et al: Nitrated alpha-synuclein-activated microglial profiling for Parkinson's disease. J Neurochem 2008, 104(6):1504-1525

56. Fellner $L$, Irschick $R$, Schanda $K$, et al: Toll-like receptor 4 is required for alpha-synuclein dependent activation of microglia and astroglia. Glia 2013, 61(3):349-360.

57. Kim C, Ho DH, Suk JE, et al: Neuron-released oligomeric alpha-synuclein is an endogenous agonist of TLR2 for paracrine activation of microglia. Nat Commun 2013, 4:1562

58. Beraud D, Twomey M, Bloom B, et al: Alpha-synuclein alters toll-like receptor expression. Front Neurosci 2011, 5:80

59. Lee SB, Park SM, Ahn KJ, Chung KC, Paik SR, Kim J: Identification of the amino acid sequence motif of alpha-synuclein responsible for macrophage activation. Biochem Biophys Res Commun 2009, 381(1):39-43.

60. Codolo G, Plotegher N, Pozzobon T, et al: Triggering of inflammasome by aggregated alpha-synuclein, an inflammatory response in synucleinopathies. PLoS One 2013, 8(1):e55375.

61. Couch Y, Alvarez-Erviti L, Sibson NR, Wood MJ, Anthony DC: The acute inflammatory response to intranigral alpha-synuclein differs significantly from intranigral lipopolysaccharide and is exacerbated by peripheral inflammation. J Neuroinflammation 2011, 8:166. 
62. Alvarez-Erviti L, Couch Y, Richardson J, Cooper JM, Wood MJ: Alphasynuclein release by neurons activates the inflammatory response in a microglial cell line. Neurosci Res 2011, 69(4):337-342.

63. Gao HM, Kotzbauer PT, Uryu K, Leight S, Trojanowski JQ, Lee VM: Neuroinflammation and oxidation/nitration of alpha-synuclein linked to dopaminergic neurodegeneration. J Neurosci 2008, 28(30):7687-7698

64. Gao HM, Zhang F, Zhou H, Kam W, Wilson B, Hong JS: Neuroinflammation and alpha-synuclein dysfunction potentiate each other, driving chronic progression of neurodegeneration in a mouse model of Parkinson's disease. Environ Health Perspect 2011, 119(6):807-814.

65. Rubartelli A, Lotze MT: Inside, outside, upside down: damage-associated molecular-pattern molecules (DAMPs) and redox. Trends Immunol 2007, 28(10):429-436.

66. Golde TE, Miller VM: Proteinopathy-induced neuronal senescence: a hypothesis for brain failure in Alzheimer's and other neurodegenerative diseases. Alzheimers Res Ther 2009, 1(2):5.

67. Salminen A, Ojala J, Kauppinen A, Kaarniranta K, Suuronen T: Inflammation in Alzheimer's disease: amyloid-beta oligomers trigger innate immunity defence via pattern recognition receptors. Prog Neurobiol 2009, 87(3):181-194.

68. Czirr E, Wyss-Coray T: The immunology of neurodegeneration. J Clin Invest 2012, 122(4):1156-1163.

doi:10.1186/2051-5960-1-38

Cite this article as: Sacino et al:: Induction of CNS a-synuclein pathology by fibrillar and non-amyloidogenic recombinant $a$-synuclein. Acta Neuropathologica Communications 2013 1:38.

\section{Submit your next manuscript to BioMed Central and take full advantage of:}

- Convenient online submission

- Thorough peer review

- No space constraints or color figure charges

- Immediate publication on acceptance

- Inclusion in PubMed, CAS, Scopus and Google Scholar

- Research which is freely available for redistribution 